Быстрова T.E.

\title{
К вопросу о прецедентности в творчестве А.П.Чехова (на материале рассказа А.П.Чехова «Староста (сценка)»
}

Аннотация: В статье рассматривается проблема прецедентности в текстах художественной литературы, приводится определение понятия «прецедентный текст», раскрывается суть этого явления в современном русском языке. Также в статье говорится о прецедентных именах как одной из разновидности прецедентных текстов. В данной работе исследуются различные типы прецедентных имен на материале рассказа А.П.Чехова «Староста (сценка)». Многие реалии московской жизни конца ХІХ века, которые являются сами по себе прецедентными именами того времени, получили отражение в творчестве А.П.Чехова. В данном исследовании использовался метод лингвостилистического анализа текстов. Диапазон прецедентных имен в художественных произведениях А.П.Чехова очень широк,на примере одного рассказа можно выявить несколько типов прецедентных имен, наиболее характерных для творчества этого писателя. Новизна работы состоит в том, что прецедентность на материале прозы А.П.Чехова ранее не рассматривалась исследователями в области языка, культуры и литературы. В частности, прецедентные имена - это особый и мало изученный пласт в творчестве классика русской литературы А.П.Чехова. Например, в рассказе "Староста (сценка)" можно наблюдать следующие типы прецедентных имен: фамилии известных личностей - современников Чехова: юристов, ученых, композиторов и т.д., географические названия, крылатые выражения.

Ключевые слова: Прецедентность, прецедентный текст, прецедентное имя, творчество А.П.Чехова, Ю.Н.Караулов, крылатые выражения, хрестоматийность, текст, факт культуры, Москва.

Review: The article is devoted to the problem of precedentiality in the texts of fiction, provides a definition of the term 'precedent text' and describes this phenomenon in the modern Russian language. The author of the article also touches upon precedent names as a type of precedent texts. Different types of precedent names are studied based on the case study of Anton Chekhov's short story "The Headman (A Sketch) ". Many realities of Moscow life of the end of the XIX century, which themselves repersent precedent names of those times, were reflected in the works of Anton Chekhov. The method of linguostylistic analysis of texts is used in this research. There a wide range of precedent names which can be found in the works of Anton Chekhov. According to the author, by analyzing one of the short stories of Anton Chekhov it is possible to identify several types of precedent names that are most typical for the creative work of this writer. The novelty of this research is caused by the fact that precedentiality in the prose of Anton Chekhov was not addressed previously by researchers in the field of language, culture and literature. In particular, precedent names are a special yet understudied aspect of the creative work of a great Russia's classical author Anton Chekhov. For example, in the short story 'The Headman (A Sketch) one can observe the following types of precedent names: last names of famous persons who were Chekhov's contemporaries such as lawyers, scientists, composers, and etc., geographical names and eloquent expressions.

Keywords: Precedentiality, precedent text, precedent name, Anton Chekhov's creative work, Yu. Karaulov, eloquent expression, chrestomathy, text, cultural fact, Moscow.

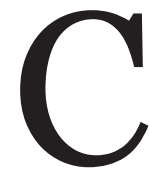

овременная лингвистика признала своим главным объектом текст, т.к. человек в своей «специфике всегда выражает себя (говорит), то есть создаёт текст» [1, с. 301]. Вся наша жизнь проходит в текстовом окружении, из текстов различных типов мы получа- ем большую часть информации о мире. Помимо необходимости дать доступную информацию, человек ищет соответствующие средства связи (метафоры, цитаты, пословицы), позволяющие ярко, быстро, эмоционально и лаконично воздействовать на читателя. 
Понятие прецедентности сравнительно недавно вошло в научный обиход, однако очень быстро заняло заметное место в терминологической парадигме современной лингвистики. Первым к понятию прецедентных текстов в своей работе "Русский язык и языковая личность” обратился исследователь Ю.Н. Караулов. Прецедентные тексты определены им как тексты, «(1) значимые для той или иной личности в познавательном и эмоциональном отношениях, (2) имеющие сверхличностый характер, то есть хорошо известные широкому окружению данной личности, включая ее предшественников и современников, и, наконец, такие, (3) обращение к которым возобновляется неоднократно в дискурсе данной языковой личности» [3, с.216].

Прецедентные тексты Ю.Н. Караулов характеризовал через понятие «хрестоматийность», которое распространяется не только на художественные тексты известных классиков литературы, включенных в общеобразовательный курс литературы. Для представителей русской культуры такими хрестоматийными текстами, вне сомнения, являются произведения А.С. Пушкина, М.Ю. Лермонтова, Н.В. Гоголя и др. В круг прецедентных текстов также входят тексты, существовавшие до художественной литературы «в виде мифов, преданий, устно-поэтических произведений», а также «библейские тексты и виды устной народной словесности (притча, анекдот, сказка и т.п.), публицистические произведения историко-философского и политического звучания». В число хрестоматийных текстов, таким образом, не обязательно входят тексты, включенные в программу общеобразовательной школы, а тексты, о которых «говорящие так или иначе знают» [3, с.216]. Следствием хрестоматийности и общеизвестности прецедентных текстов является их «реинтерпретируемость», в результате которой прецедентные тексты «перешагивают рамки словесного творчества, где исконно возникли, воплощаются в других видах искусств (драматическом спектакле, поэзии, опере, балете, живописи, скульптуpe)» [3, с. 217]. Таким образом, к определяющим характеристикам прецедентных текстов Ю.Н. Караулов относит: хрестоматийность и общеизвестность; эмоциональную и познавательную ценность; реинтерпретируемость, проявляющуюся в их многократной интерпретации (воспроизводимости) в различного рода текстах и дискурсах, это в итоге ведет к тому, что такие тексты становятся «фактом культуры» [3, с. 217].

Термин «прецедентный текст» оказался плодотворным в плане создания большого количества производных терминов, среди которых особое место занимает такой термин, как «прецедентное имя». Вслед за В.В.Красных мы понимаем прецедентное имя как «индивидуальное имя, связанное или с широко известным текстом, как правило, относящимся к прецедентным (например, Печорин, Теркин), или с прецедентной ситуацией (например, Иван Сусанин); это своего рода сложный знак, при употреблении которого в коммуникации осуществляется апелляция не к собственно денотату, а к набору дифференциальных признаков данного прецедентного имени; может состоять из одного (Ломоносов) или более элементов (Куликово поле), обозначая при этом одно понятие» [2].

В данной статье мы рассмотрим московские реалии конца XIX века на материале рассказа Чехова «Староста (сценка)» (1885). Рассказ впервые был опубликован в «Петербургской газете» в сентябре 1885 года в отделе «Летучие заметки» с подписью: «А.Чехонте».

В рассказе А.П.Чехова «Староста (сценка)» можно выделить несколько типов прецедентных имен.

1)Фамилии известных личностей юристов, ученых, композиторов и т.д. Например, герой рассказа, староста с говорящим именем Шельма, рассказывает трактирщику, как тяжело «вести крестьянские дела»: «это такая политика, что и Бисмарка мало». (Бисмарк - Отто Эдуард Леопольд фон БисмаркШенхаузен (1815 - 1898), первый канцлер Германской империи, осуществивший план объединения Германии и прозванный «железным канцлером»). Староста рассуждает, что такого юриста, как он, надо поискать, хотя «скопинского дела я тебе не решу и за Сарру Беккер не возьмусь, но ежели что по крестьянской части, то... никто супротив меня не годится». ( Скопинское дело - Будучи директором Скопинского городского общественного банка, Иван Гаврилович Рыков добился того, чтобы в мало кому известный уездный город на Рязанщине рекой потекли деньги со всей России. Предприниматель сулил вкладчикам баснословные проценты, но слова не держал, а злоупотребления банка приобрели небыва- 
лый размах. Банкир хитростью заручился поддержкой высокопоставленных лиц губернии, и вскоре в его руках оказалась власть над всей округой. В конце концов банк лопнул, и в Скопин хлынули обманутые вкладчики, все еще надеявшиеся вернуть свои деньги. Вскоре их число превысило население городка, над ним нависла угроза эпидемии, и власти были вынуждены начать разбирательство этого авантюрного дела. Суд над Рыковым проходил в 1884 году и вызвал огромный интерес общественности, привлек к себе внимание многих российских журналистов. Дело рассматривал Московский окружной суд. Среди репортеров, присутствовавших на процессе, был и начинающий писатель Антон Павлович Чехов, которому «Петербургская газета» предложила делать ежедневные репортажи из зала суда. Так возник цикл очерков Чехова «Дело Рыкова и комп.». Чехову скопинское дело дало много впечатлений и идей, которые получили развитие в таких рассказах, как «Идиллия увы и ах!», «Беда», «Маска», «Человек в футляре» и др.), Сарра Беккер - Судебный процесс об убийстве ростовщиком Мироновичем тринадцатилетней Сарры Беккер слушался в Санкт-Петербургском окружном суде в 1884 г., по протесту прокурора был возобновлен и широко освещался в печати (например, большие статьи в газете «Русский курьер», 1885 , N 47, 18 февраля, N 65, 8 марта). Шельма хвастается дальше: «Будь ты хоть Ломоносов, хоть Бетховен, но ежели в тебе нет моего таланта, то лучше и не суйся». (Ломоносов Михаил Васильевич (1711 - 1765) - первый русский ученый-естествоиспытатель мирового значения, энциклопедист, химик, физик, астроном, географ, приборостроитель, металлург, геолог, поэт, художник, филолог, историк, один из основателей Московского университета), Людвиг ван Бетховен (1770-1827) - немецкий композитор, пианист, представитель «венской классической школы», один из наиболее исполняемых композиторов в мире). Дальше староста рассказывает про дело «репловского старосты»: «Хорошее дело, политичное! Плевако бы осекся, а у меня выгорело». (Плевако Федор Никифорович (1842-1909) - известный адвокат, юрист, судебный оратор).

2)Географические названия. Староста Шельма рассказывает трактирщику: «Есть...недалече от Москвы колокольный завод». Дальше староста поясняет, почему бывшего крестьянина, а теперь старше- го мастера на заводе в Москве, потянуло в родное село: «Поезжай ты в Америку, сядь там по горло в сторублевки, а тебя все в свой трактир тянуть будет».

3)Кръляатъєе въражения. Главный герой рассказа рассуждает: «Почему... меня мужики любят? Почему они ко мне, как мухи, льнут?» Дальше староста рассказывает историю разбогатевшего крестьянина, приехавшего в родное село и не угостившего односельчан водкой. Стали односельчане думать, «как из Евдокима сто рублей выцыганить. Думали всем миром, думали и ничего не выдумали. Ходят около избы и только пужают: мы тебя, да я тебя! А он сидит себе и в ус не дует». Евдоким рассуждает так: «Чего ж мне бояться? Вольная я птица!» ... Крестьяне поняли, что «денег им не видать, как ушей своих», и стали думать, как бы «этой вольной птице за неуважение крылья ощипать». Крестьяне за помощью идут к старосте, и он видит, что «всё как на ладони видно, все Евдокимовы права налицо... сам чёрт не прищепится». Евдоким отказывается от новой должности, говорит, что должен вернуться в город, потому что там без него «хозяин как без рук», и «летит, как угорелый, к волостному старшине», объяснить, что не может остаться в селе и быть сельским старостой.

Наконец, в рассказе «Староста (сценка)» А.П.Чехова можно наблюдать единичные случаи употребления прецедентных текстов. Например, староста рассказывает, как старшего мастера, работавшего в Москве, потянуло в родное село: «Не с чего, кажись бы, старшему мастеру скучать, но, знаешь, дым отечества». («И дым отечества нам сладок и приятен» - цитата из комедии А.С.Грибоедова «Горе от ума» (1824), ср. слова Чацкого: «Когда ж постранствуешь, воротишься домой, И дым отечества нам сладок и приятен». А.С.Грибоедов, в свою очередь, в своей пьесе процитировал строку из стихотворения «Арфа» (1798) Г.Р.Державина: «Мила нам добра весть о нашей стороне. Отечества и дым нам сладок и приятен». Также эту державинскую строку цитировали поэты К.Батюшков, П.Вяземский и др. Сама мысль о сладости «дыма отечества» принадлежит легендарному поэту Древней Греции Гомеру (IX в.до н.э.), который в поэме «Одиссея» говорит, что Одиссей был готов и на смерть, лишь бы «видеть хоть дым, от родных берегов вдалеке восходящий» (речь идет о дыме 
очагов родной для путешественника Итаки. Позже эту же мысль повторит римский поэт Овидий (Публий Овидий Назон, 43 г. до н.э. - 18 г. н.э.) в «Понтийских посланиях». Сосланный на побережье Черного моря, он мечтал увидеть «дым отечественного очага». На основе этих строк возникла и известная римская пословица: «Dulcis fumus patriae»Сладок дым отечества. В державинское время это изречение было широко известно; так, на заглавном листе журнала «Российский музеум» $(1792-1794)$ находился эпиграф «Dulcis fumus patriae»).

Староста Шельма хвастается, как он легко помог «репловскому старосте»: «Ларчик про- сто открывается. В самом законе загадка разгадывается». («А ларчик просто открывался» - цитата из басни И.А.Крылова «Ларчик» (1808). Цитата используется, когда говорят о каком-нибудь деле, при разрешении которого нечего было мудрить).

Таким образом, в рассказе А.П.Чехова «Староста (сценка)» (1885) можно наблюдать как сами прецедентные тексты, так и прецедентные имена. В рассказе можно выделить следующие типы прецедентных имен: 1) фамилии известных личностей - юристов, ученых, композиторов и т.д.; 2) географические названия; 3) крылатые выражения.

\section{Библиография:}

1. Бахтин М.М. Эстетика словесного творчества. - М., 1979.

2. Захаренко И.В., Красных В.В., Гудков Д.Б., Багаева Д.В. Прецедентное высказывание и прецедентное имя как символы прецедентных феноменов. // Язык, сознание, коммуникация. Вып.1. - М., 1997.

3. Караулов Ю.Н. Русский язык и языковая личность. - М., 1987.

4. Серов В. Энциклопедический словарь крылатых слов и выражений. - М.: Локид-Пресс, 2003.

5. Сытин П.В. Из истории московских улиц. - М., 1948.

6. Чехов А.П. Среди милых москвичей. - М.: Правда, 1988.

7. Чехов А.П. Полное собрание сочинений в 30 тт. - М.: Наука, 1974-1986.

8. Чехов М.П. Антон Чехов и его сюжеты. - М., 1923.

\section{References (transliterated):}

1. Bakhtin M.M. Estetika slovesnogo tvorchestva. - M., 1979.

2. Zakharenko I.V., Krasnykh V.V., Gudkov D.B., Bagaeva D.V. Pretsedentnoe vyskazyvanie i pretsedentnoe imya kak simvoly pretsedentnykh fenomenov. // Yazyk, soznanie, kommunikatsiya. Vyp.1. - M., 1997.

3. Karaulov Yu.N. Russkii yazyk i yazykovaya lichnost'. - M., 1987.

4. Serov V. Entsiklopedicheskii slovar' krylatykh slov i vyrazhenii. - M.: Lokid-Press, 2003.

5. Sytin P.V. Iz istorii moskovskikh ulits. - M., 1948.

6. Chekhov A.P. Sredi milykh moskvichei. - M.: Pravda, 1988.

7. Chekhov A.P. Polnoe sobranie sochinenii v 30 tt. - M.: Nauka, 1974-1986.

8. Chekhov M.P. Anton Chekhov i ego syuzhety. - M., 1923. 